\title{
Profile of Leachate and Sea Water in the Waste Processing Area Suwung, Denpasar, Bali
}

\author{
Pande Kadek Ari Iswari ${ }^{1 *}$, I Wayan Restu ${ }^{1}$, and Ni Made Ernawati ${ }^{1}$ \\ ${ }^{1}$ Department of Aquatic Resources Management, Faculty of Marine and Fisheries, Udayana University \\ Jl. Kampus Unud Bukit Jimbaran, Kuta Selatan, Badung, Bali \\ *Corresponding author: ariiswari43@gmail.com
}

\begin{abstract}
This study aims to determine the profile of leachate, and seawater in the Suwung waste processing area (TPA Suwung). The method used in this research was descriptive quantitative. The results showed a high profile of untreated leachate with a TSS value of $9.407 \mathrm{mg} / \mathrm{L}$, $\mathrm{pH}$ with a value of 8.17 , DO with a value of $0.063 \mathrm{mg} / \mathrm{L}$, BOD with a value of $375.5 \mathrm{mg} / \mathrm{L}$, and COD with a value of $5.776 \mathrm{mg} / \mathrm{L}$. The treated leachate with a TSS value of $4,987 \mathrm{mg} / \mathrm{L}, \mathrm{pH}$ with a value of 8.52 , DO with a value of $0.063 \mathrm{mg} / \mathrm{L}$, BOD with a value of $321.9 \mathrm{mg} / \mathrm{L}$, and a COD value with a value of 3.069 mg/L. Meanwhile, the seawater profile was classified as good with parameter values of TSS with a value of $76 \mathrm{mg} / \mathrm{L}, \mathrm{DO} 7.54 \mathrm{mg} / \mathrm{L}, \mathrm{pH} 7.54, \mathrm{BOD}$ with a value of $13.6 \mathrm{mg} / \mathrm{L}$, COD with a value of $64 \mathrm{mg} / \mathrm{L}$. The existence of TPA Suwung has a negative impact and influence on seawater in the area. Revitalization efforts are needed to carry out leachate water treatment so that the effluent quality can be improved for the quality of water around TPA Suwung.
\end{abstract}

Keywords: environment; leachate; suwung; waste

\section{INTRODUCTION}

The Suwung Final Processing Site (TPA), which is located in Suwung Kangin Village, South Denpasar District, Denpasar City, Bali Province, which is 500 meters south of the city center, is one of the largest garbage reservoirs in Bali. This TPA accommodates a variety of waste both household, market, and industrial waste that is produced, and the waste collected is very diverse, from organic waste to non-organic waste that should be used and recycled by humans. The existence of TPA Suwung as a place for the garbage disposal to pile up approximately $740,937 \mathrm{~m}^{3} /$ day of waste per day originating from Denpasar City and Badung Regency resulting in a large accumulation of garbage Oka and Ngurah [4]. In addition to solid organic and non-organic waste, this waste can cause liquid waste produced from the pile of waste in the form of leachate. Leachate can penetrate the soil causing soil and groundwater pollution directly because leachate contains various organic and inorganic chemical compounds as well as several pathogens Susanto [5]. To overcome the problem of leachate, leachate treatment efforts are needed at the TPA (Final Processing Site) location. Leachate can have an impact on the environment around the landfill site. The location of the Suwung TPA which is directly opposite Benoa Bay has the potential to disrupt the environment. However, information on how much potential disruption to the waters of Benoa Bay is still very limited because data on the quality of leachate flowing into Benoa Bay waters is also very limited. Therefore, we need a study to determine the profile of leachate water quality and seawater quality in the Suwung TPA area.

\section{METHODS}

The method used in this research is descriptive with quantitative data obtained with an observation approach. The descriptive method is a method that describes a symptom, event, and occurrence that occurs at the Final Waste Processing Site (especially leachate treatment), and seawater. Quantitative data from observations and measurements of an object or variable where the number of leachate parameter values, seawater. Samples were taken using the purposive sampling method, which is to determine the sampling location based on consideration of the distribution of the impact of leachate on seawater.

\section{Leachate and Seawater Sampling and Measurement}

Leachate samples were taken from the research location with 4 points for each sample point taken 3 times for sampling. The sample leachate is taken close to the pile of garbage and close to the mangrove as much as 1.5 liters. And seawater sampling with 1 point for each sample point taken 3 times sampling. Samples were taken as much as 1.5 liters and accommodated in sample bottles, then samples of leachate were taken to be measured for $\mathrm{pH}, \mathrm{DO}$, TSS, BOD, and COD at the UPTD. Environmental Laboratory of Bali Province, while samples of seawater 
samples were brought for DO, TSS, TDS, BOD, COD, Oil, and Fat measurements at the UPTD. Bali Provincial Health Office Laboratory.

\section{RESULT AND DISCUSSION}

\section{Leachate and seawater profiles at Suwung landfill}

The TSS content of untreated leachate was $9,407 \mathrm{mg} / \mathrm{L}$, processed leachate $4,987 \mathrm{mg} / \mathrm{L}$, and $76 \mathrm{mg} / \mathrm{L}$ in seawater. The TSS value in the waters around TPA Suwung ranges from $76 \mathrm{mg} / \mathrm{L}$ to $9,407 \mathrm{mg} / \mathrm{L}$. The highest TSS value is found in untreated leachate, which is $9,407 \mathrm{mg} / \mathrm{L}$ and the low TSS value is in seawater, which is $75.67 \mathrm{mg} / \mathrm{L}$ can be seen in Figure 1.

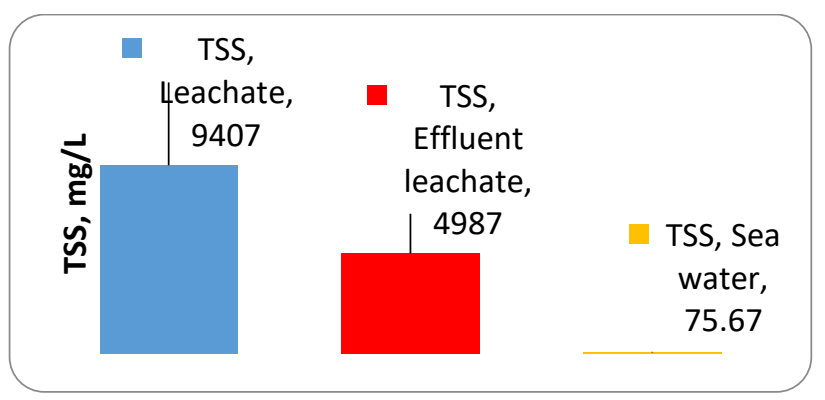

Figure 1. TSS Value

Leachate is the liquid waste that is generated as a result of the entry of external water into the waste pile, dissolving and rinsing dissolved materials, including organic matter resulting from waste decomposition so that the quantity and quality of water vary widely and fluctuates. In Figure 2 , it is known that the leachate (unprocessed) sample collection obtained a high TSS value or level of 9,407 as the leachate treatment (processed) decreased, namely with a value of 4,987. According to Ika Wahyuni [2] Turbidity in wastewater can make it difficult for sunlight to enter the water, thus affecting oxygen regeneration through photosynthesis. At the leachate inlet, the TSS value was $250 \mathrm{mg} / \mathrm{L}$, then after undergoing processing at the Jetis TPA WWTP it produced a TSS value of $58 \mathrm{mg} / \mathrm{L}$. The TSS value in the waters of Serangan Island with a value of $76 \mathrm{mg} / \mathrm{L}$ is classified as low and is still below the quality standard for biota. This is following the statement of Siburian [6] which states that the TSS measurement results for the Seawater of Kalabahi Public Port on A1 are 67.94 $\mathrm{mg} / \mathrm{L}, \mathrm{A} 2$ is $78.68 \mathrm{mg} / \mathrm{l}$, and on A3 it is $74.48 \mathrm{mg} / 1$. The results of the three measurements were still below the established quality standard, namely $80 \mathrm{mg} / 1$. which states that TSS can consist of organic, inorganic particles, or mixtures thereof.

The $\mathrm{pH}$ content of untreated leachate was 8.17, treated leachate was 8.52 and seawater was 7.54. The $\mathrm{pH}$ value in the waters around TPA Suwung ranges from 7.54 to 8.52 . A high $\mathrm{pH}$ value is found in treated leachate water, which is 8.52 and a low TSS value is found in seawater, namely, 7.54, which can be seen in Figure 2.

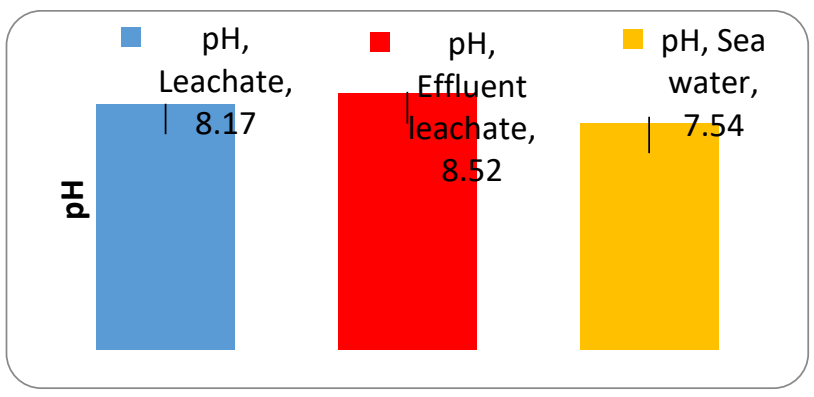

Figure 2. $\mathrm{pH}$ Value

A sampling of leachate water (unprocessed) obtained a $\mathrm{pH}$ value or level of 8.17 along with the occurrence of leachate treatment (already processed) increased with a value of 8.52. According to Nani [3] organoleptically, the leachate of the research sample smelled pungent, but $\mathrm{pH}$ parameters and organic substances showed a value that did not meet quality standards. The $\mathrm{pH}$ required as leachate is in the range of 6.5-9 while the test results show a pH that is below this range, namely 5 . A pH value of 5 indicates a fairly high acidity. Leachate samples were taken from the leachate inlet around the TPS. The acidic $\mathrm{pH}$ of the sample leachate can be caused by the influence of lighting the $\mathrm{pH}$ value which ranges from 5.3-5.4. The $\mathrm{pH}$ in the waters of Serangan Island with a value of 7.54 is classified as low and below the quality standard for marine biota, namely 6 9. This is following the statement of Saraswati [7]. Spatially, the $\mathrm{pH}$ value in the northern waters of Serangan at the time of the study is seen to be evenly distributed in almost all points. Although the fluctuation graph shows that the $\mathrm{pH}$ value has decreased and increased, the variation shown is low, which is below 8 .

The DO content of untreated leachate is $0.063 \mathrm{mg} / \mathrm{L}$, treated leachate is $0.073 \mathrm{mg} / \mathrm{L}$ and in seawater $3.87 \mathrm{mg} /$ $\mathrm{L}$. The $\mathrm{pH}$ value in the waters around TPA Suwung ranges from $0.063 \mathrm{mg} / \mathrm{L}$ to $3.87 \mathrm{mg} / \mathrm{L}$. A high DO value is found in seawater, namely $3.86 \mathrm{mg} / \mathrm{L}$, and a low TSS value is found in untreated leachate water, which is $0.063 \mathrm{mg} / \mathrm{L}$ can be seen in Figure 3.

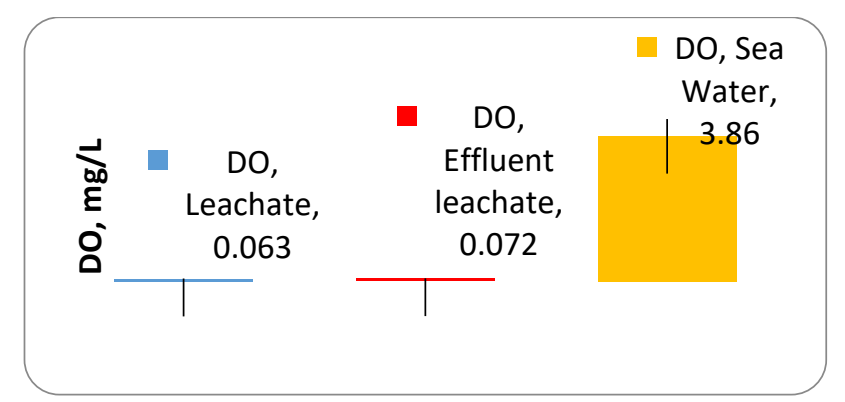

Figure 3. DO Value 
A sampling of leachate water (unprocessed) obtained a value or DO level of 0.063 along with the occurrence of leachate water treatment (already treated) increased with a value of 0.073 . The low DO value is due to the process of organic matter caused by organisms that use oxygen so that the availability of dissolved oxygen decreases in the leachate. This can be supported by Arbain's [1] statement which states that DO concentrations at AL1 are $0.8 \mathrm{mg}$ and AL2 are 0.6. DO concentration has not been included in the quality standard for domestic wastewater quality. The low DO value is due to the decomposition of organic matter by aerobic microorganisms that use oxygen so that the availability of dissolved oxygen decreases. The DO value in the leachate sample is closely related to organic matter as a pollutant, meaning that organic matter can reduce oxygen in the water. In general, if the DO value is low, this indicates that there will be more organic pollutants in the number of microorganisms, both pathogenic and non-pathogenic. DO in Serangan Island waters with a value of $3.87 \mathrm{mg} / \mathrm{L}$ this value is classified as low and below the quality standard for marine biota $>5$ $\mathrm{mg} / \mathrm{L}$. This is in accordance with the statement of Saraswati [7]. The surface DO value obtained in northern Serangan waters ranges from $3 \mathrm{mg} / \mathrm{L}$ to $4.4 \mathrm{mg} / \mathrm{L}$. The DO value range is low and below the seawater quality standard for marine biota, which is $>5 \mathrm{mg} / \mathrm{L}$. The low range of DO values is thought to be due to the morning sampling time. The DO value is estimated to increase with increasing sunlight intensity and the photosynthesis process.

The BOD content of untreated leachate was $375.7 \mathrm{mg} /$ $\mathrm{L}$, treated leachate $321.887 \mathrm{mg} / \mathrm{L}$ and $13.6 \mathrm{mg} / \mathrm{L}$ in seawater. The BOD value in the waters around TPA Suwung ranges from $13.6 \mathrm{mg} / \mathrm{L}$ to $375.5 \mathrm{mg} / \mathrm{L}$. A high BOD value is found in untreated leachate water, namely $375.5 \mathrm{mg} / \mathrm{L}$ and a low TSS value is found in seawater, namely $13.6 \mathrm{mg} / \mathrm{L}$ can be seen in Figure 4.

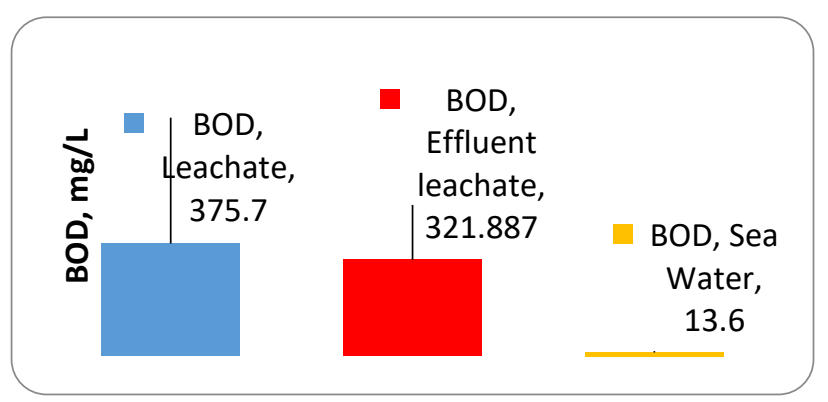

Figure 4. BOD Value

The COD content of untreated leachate is $5,776 \mathrm{mg} / \mathrm{L}$, treated leachate $3069,623 \mathrm{mg} / \mathrm{L}$ and in seawater $63 \mathrm{mg} /$ L. The COD value in the waters around TPA Suwung ranges from $63 \mathrm{mg} / \mathrm{L}$ to $5,776 \mathrm{mg} / \mathrm{L}$. A high COD value is found in untreated leachate water, namely $5.776 \mathrm{mg} / \mathrm{L}$ and a low TSS value is found in seawater, which is $63 \mathrm{mg}$ / $\mathrm{L}$ can be seen in Figure 5

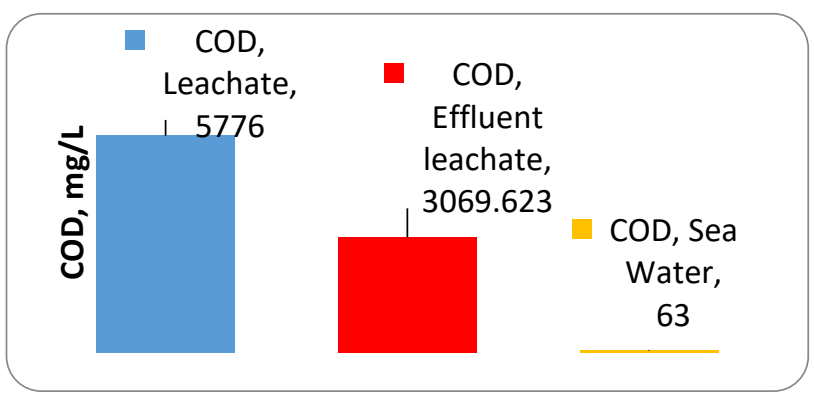

Figure 5. COD Value

BOD and COD in the leachate (unprocessed) water sample obtained the value or BOD level with a value of 375.7 along with the occurrence of leachate treatment (already treated) decreased, namely 321.9. And the COD value in the leachate water sample (unprocessed) obtained the value or COD level with a value of 5,776 along with the occurrence of leachate treatment (unprocessed) experiencing a decrease of 3,070. This can be supported by Ika Wahyuni [2] This is in accordance with TPA Jetis which has been operating for 21 years. Based on the ratio of BOD / COD values of 0.45 , the leachate in Jetis landfill has a high level of biodegradability. The ratio values in the range $0.4-0.6$ are an indication that the organic matter in leachate is easily degraded. This is evidenced by a decrease in BOD and COD levels at the IPAL outlets. After going through the processing process in the WWTP unit, the concentration of BOD became $117.6 \mathrm{mg} / \mathrm{L}$ and COD was $271.36 \mathrm{mg} / \mathrm{L}$, which values have met the quality standard. The BOD value in Serangan Island waters with a value of 13.6 is classified as low below the quality standard for biota. This is in accordance with the statement of Saraswati [7]. Based on the results of the analysis of the BOD value in the northern waters of Serangan, it is obtained a range of $2.8 \mathrm{mg} / \mathrm{L}$ to $5.4 \mathrm{mg} / \mathrm{L}$. The COD value in Serangan Island waters with a value of 63 is low below the quality standard for biota. This is in accordance with the statement of Wibowo [8]. This is because the organic material is deliberately broken down chemically using a strong oxidizer of potassium bichromate under acidic and hot conditions with silver sulfate catalyst, so that all kinds of organic materials, both easy to decompose and complex and difficult explained, will be oxidized [9-10].

\section{CONCLUSION}

The leachate and sea water profiles around the Suwung TPA management have high values on the TSS, BOD, and COD parameters for the management of the Suwung TPA. 
This has a negative impact on the surrounding environment.

\section{ACKNOWLEDGE}

Thank you to DLH Bali Province and UPT. Management of TPA Suwung which has helped this research process.

\section{REFERENCES}

[1] Arbaine. 2013. Study of Leachate Water Quality Groundwater Quality Around the Jetis Waste TPA (Final Processing Site), Pakem Village, Gebang District, Purworejo, Central Java. Central Java: Indonesia. Soil and Water Journal, 15(1),1-9

[2] Ika Wahyuni. 2018. Study of Leachate Water Quality on Groundwater Quality Around the Jetis Waste TPA (Final Processing Site), Pakem Village, Gate District, Purworjo, Central Java. Journal of Soil and Water (Soil and Water Journal). 5(1) 1-9.

[3] Nani A. 2018. The Effect of Leachate on $\mathrm{pH}$ and Organic Substances in Groundwater in Temporary Shelters, Pahandut Village, Palangkaraya City. J. of Humans and the Environment. 25(2) 60-65.

[4] Oka., and Ngurah. 2014. Juridical Review of Land Utilization of Suwung Kauh Village as a Final Processing Site (TPA) Suwung, Denpasar, Bali, Bali: Indonesia. Udayana Faculty of Law.

[5] Susanto. 2014. Effectiveness of Heavy Metal Adsorption on Leachate Using Zeolite Activated
Carbon Media, and Silica Gel at TPA Tiengkung, Batu. Stone: Indonesia. Journal of Natural Resources and Environment, 2(1), 2-5

[6] Siburian. R. 2017. Analysis of the Quality of Marine Waters on Activities in the Port of Wangaipu-Alor, East Sumba. East Sumba: Indonesia. Department of Chemistry, Faculty of Mathematics and Natural Sciences, University of North Sumatra, Medan. Medan: Indonesia. Journal of Community Service, 23(1), 228-230.

[7] Saraswati A.R.G.L.N. 2017. Analysis of Water Quality in North Serangan Island Waters Based on Seawater Quality Standards. Journal of Marine and Aquatic Sciences. 3(2) 163-170.

[8] Wibowo M. 2020. Study of the Quality of Sea Waters Around the Estuary of the Jelitik River, Sungailiat District - Bangka Regency. Precipitation Journal. 17(1) 29-37.

[9] Damanhuri, T.P 2010. Management of Leachate in TPA Garbage in Relation to Prevention of Environmental Pollution, Proceedings of the National Seminar on Environmental Management-About the Future. Journal of Environmental Engineering ITB. ISBN 979-8456-00-9

[10] Simanjuntak, M. 2012. Seawater Quality Seen from Aspects of Nutrients, Dissolved Oxygen and $\mathrm{pH}$ in Banggai Waters, Southeast Sulawesi. Journal of Tropical Marine Science and Technology. 4(2), 290303. 